Jurnal Konstruksi Hukum | ISSN: XXXX | E-ISSN: XXXX Vol. 1, No. 2, Oktober 2020, Hal. 310-314| Available online at https://www.ejournal.warmadewa.ac.id/index.php/jukonhum

DOI: https://doi.org/10.22225/jkh.1.2.2564.310-314

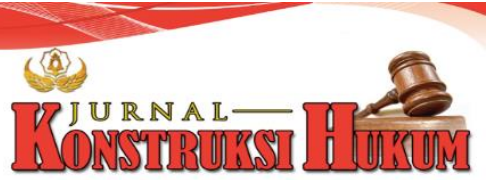

\title{
EUTANASIA DALAM PERSPEKTIF HAK ASASI MANUSIA DAN HUKUM POSITIF DI INDONESIA
}

\author{
I Gusti Agung Gede Utara Hartawan, Anak Agung Sagung Laksmi Dewi, I Nyoman Sutama \\ Fakultas Hukum Universitas Warmadewa, Denpasar-Bali, Indonesia
}

\begin{abstract}
Abstrak
Peraturan perundang-undangan tentang eutanasia sudah disetujui dan diberlakukan di Negara eropa seperti Belanda. Hal ini memberikan peluang bagi keluarga pasien yang mempunyai penyakit yang tidak dapat disembuhkan oleh ilmu kedokteran untuk mengakhiri kehidupan pasien dengan tujuan menghentikan penderitaan pasien. Di Indonesia, saat ini, tidak ada Norma Hukum yang mengatur tentang eutanasia. Penelitian ini bertujuan untuk menganalisis tentang eutanasia dipandang dari perspektif Hak Asasi Manusia dan mengetahui eutanasia dipandang dari perspektif hukum positif yang berlaku di Indonesia. Penelitian termasuk sebagai penelitian normatif dengan pendekatan konseptual dan peraturan perundang-undangan. Hasil penelitian ini menunjukan bahwa eutanasia bertentangan dengan pasal 28A, pasal 28G ayat (2), dan pasal 28I ayat (1) Undang-Undang Dasar Negara Republik Indonesia 1945 (UUD Negara Republik Indonesia 1945) dan pasal 338, 340, 344,345 KUHP. Dalam hal ada permintaan eutanasia dari pasien atau keluarga pasien, maka dokter harus menolak permintaan tersebut dan putusan pelaksanaan eutanasia sebaiknya menunggu penetapan putusan pengadilan.
\end{abstract}

Kata Kunci: Eutanasia; Hak asasi manusia; Hukum Indonesia

\begin{abstract}
Euthanasia legislation has been approved and enforced in European countries such as the Netherlands. This provides a chance for the patient's family with an incurable disease to end the patient's life in order to end the patient's suffering. In Indonesia, currently there are no legal norms that regulate euthanasia. This study aims to analyze euthanasia from a human rights perspective and to know euthanasia from a positive legal perspective in Indonesia. Research is included as normative research with a conceptual approach and statutory regulations. The results of this study indicate that euthanasia is contrary to article 28A, article $28 G$ paragraph (2), and article 28 I paragraph (1) of the 1945 Constitution of the Republic of Indonesia and articles 338, 340, 344, 345 of the Criminal Code. In the event that there is a request for euthanasia from the patient or the patient's family, the doctor must reject the request and the decision to implement euthanasia should wait for a court decision.
\end{abstract}

Keywords: Euthanasia; Human rights; Indonesian law

\section{PENDAHULUAN}

Hak asasi manusia adalah hak yang diberikan oleh Tuhan yang maha Esa saat manusia dilahirkan sehingga dianggap sebagai hak kodrat manusia. Beberapa istilah dari HAM antara lain: human right, natural right, fundamental right, civil right, dan lain-lain. Hak asasi manusia pertama kali didokumentasikan dalam Magna Charta tahun 1215. Hak asasi manusia di Indonesia diatur dalam Undang-Undang Republik Indonesia Nomor 39 Tahun 1999 tentang Hak Asasi Manusia. Dalam perubahan kedua UUD Negara Republik Indonesia 1945, unsur HAM dimasukan ke dalam bagian tersendiri, yaitu Bab XA mengenai Hak Asasi Manusia yang terdiri atas 10 pasal. Muatan HAM dalam perubahan kedua UUD Negara Republik Indonesia 1945 jauh melebihi ketentuan yang diatur dalam Undang-Undang Dasar 1945.

Beberapa penelitian tentang eutanasia telah banyak dilakukan sebelumnya seperti Baeke, Wils, \& Broeckaert (2011); Sofyan (2017); Sutarno (2020); Yustina (2018). Namun, dalam penelitian ini secara khusus membahas tentang hak pasien yang sakit parah untuk tetap hidup. Oleh karena itu, rumah sakit sebagai organisasi yang sangat kompleks, begitu juga dengan ruang terapi intensif (RTI) sebagai salah satu unit pelayanan yang sentral di rumah sakit atau dalam bahasa Inggris disebut dengan Intensive Care Unit (ICU) menghadapi berbagai persoalan yang berkaitan dengan pasien. Masalah utama yang 
dihadapi oleh keluarga pasien yang dirawat di RTI adalah ketidakpastian apakah pasien dapat disembuhkan atau tidak (Marshall et al., 2017). Dengan kata lain, berapa lama akan dirawat di RTI, berapa biaya yang diperlukan selama perawatan pasien di RTI, dan lain sebagainya. Dalam keadaan ini, kadang kala keluarga pasien pasrah dengan keadaan karena keterbatasan dana untuk membiayai pengobatan pasien. Pada akhirnya pasien meninggal tanpa mendapatkan pengobatan. Dalam ilmu kedokteran hal ini disebut dengan euthanasia (Sutarno, 2014).

Istilah eutanasia pertama kali diperkenalkan oleh penulis Yunani yang bernama Suetonis dalam bukunya yang berjudul Vitacea sarum. Eutanasia berasal dari bahasa Yunani Euthanathos. Eu berarti baik, tanpa penderitaan dan thanathos berarti mati. Eutanasia dapat diartikan mati dalam keadaan baik atau mati tanpa penderitaan. Dengan ketiadaan norma hukum yang mengatur tentang eutanasia di Indonesia, peneliti ingin menggali lebih banyak tentang euthanasia dalam kaitannya dengan hak asasi manusia dan hukum positif yang berlaku di Indonesia. Oleh Karena itu, penelitian ini bertujuan untuk mengetahui eutanasia dari perspektif hak asasi manusia dan untuk mengetahui eutanasia dari perspektif hukum positif yang berlaku di Indonesia.

\section{METODE PENELITIAN}

Penelitian ini merupakan jenis penelitian normatif. Pendekatan masalah yang digunakan adalah pendekatan konseptual dan pendekatan peraturan perundang-undangan. Pendekatan masalah dilakukan dengan melakukan kajian terhadap peraturan perundang-undangan yang berlaku dan memiliki relevansi dengan permasalahan yang dibahas sekaligus melakukan pendekatan konseptual dengan cara menganalisis permasalahan melalui konsep hukum yang diambil dari buku-buku dan literatur lainnya yang memiliki keterkaitan dengan isu yang dibahas dalam penelitian ini.

Adapun sumber data yang digunakan dalam penelitian ini, pertama bahan hukum primer sebagai data utama yaitu peraturan perundang-undangan yang berlaku di Indonesia, seperti UUD Negara Republik Indonesia 1945, Tap MPR No. XVII/MPR/1998 tentang Piagam Hak Asasi Manusia, Kitab Undang-Undang Hukum Pidana, Kitab Undang-Undang Hukum Perdata, UU Nomor 8 Tahun 1999 tentang Perlindungan Konsumen, UU Nomor 39 Tahun 1999 tentang Hak Asasi Manusia, UU Nomor 23 Tahun 2002 tentang Perlindungan Anak, UU Nomor 29 Tahun 2004 tentang Praktik Kedokteran, UU Nomor 36 Tahun 2009 tentang Kesehatan, UU Nomor 44 Tahun 2009 Rumah Sakit, Peraturan Pemerintah Nomor 26/1960 yang termuat dalam Lembaran Negara 1960 Nomor 69 tentang Janji Dokter, Peraturan Menteri Kesehatan Republik Indonesia Nomor 290 Tahun 2008 tentang Persetujuan Tindakan Kedokteran, Keputusan Menteri Kesehatan Nomor: 1778/Menkes/SK/XII/2010 tentang Pedoman Penyelenggaraan Pelayanan Ruang Terapi Intensif di Rumah Sakit, Kode Etik Kedokteran Indonesia, dan Manual Persetujuan Tindakan Kedokteran Konsil Kedokteran Indonesia 2006.

Kedua, bahan hukum sekunder yang berasal dari buku-buku, pendapat ahli hukum, dan hasil penelitian hukum. Ketiga, bahan hukum tersier yaitu Kamus Besar Bahasa Indonesia (KBBI). Teknik pengumpulan bahan hukum yang dilakukan adalah dengan metode pencatatan, yaitu bahan hukum yang dikumpulkan diklasifikasikan dengan jenis bahan hukum yang akan digunakan, seperti buku hukum, jurnal hukum, pendapat para ahli, teori hukum, dan peraturan perundang-undangan yang terkait.

\section{HASIL DAN PEMBAHASAN}

\section{Eutanasia Dipandang dari Prespektif Hak Asasi Manusia}

Indonesia sebagai Negara hukum sudah tentu Indonesia sangat menghormati HAM, seperti yang tercantum dalam Universal Declaration of Human Right ternyata telah dimuat dalam rumusan Pembukaan UUD Negara Republik Indonesia 1945. Dalam alenia pertama Pembukaan UUD Negara Republik Indonesia 1945 dinyatakan adanya pengakuan hak untuk mendapatkan kebebasan. Pengakuan pada peri kemanusiaan merupakan inti dari HAM dan pengakuan pada peri keadilan merupakan intisari negara hukum. Pada alenia kedua disebutkan Indonesia sebagai negara yang adil dan adil adalah tujuan dari negara hukum. Alenia ketiga menyebutkan setiap orang berhak untuk turut serta bebas dalam hidup kebudayaan masyarakat. Hal ini sesuai dengan pasal 27 ayat (1) Universal Declaration of Human Right. Dalam alenia keempat berisi hak asasi manusia di bidang politik, sipil, ekonomi, sosial, dan budaya. Sila-sila Pancasila yang termuat dalam alenia keempat Pembukaan UUD Negara Republik Indonesia 1945 keseluruhannya mengandung penghormatan terhadap HAM. Prinsip-prinsip HAM juga dicantumkan dalam batang tubuh UUD Negara Republik Indonesia 1945, walau semula tidak disebutkan secara eksplisit sebagai Hak Asasi Manusia (Qamar, 2016). 
Hak asasi manusia di Indonesia diatur dalam UU Nomor 39 Tahun 1999 tentang Hak Asasi Manusia. Menurut pasal 1 angka 1 UU Nomor 39 Tahun 1999 tentang Hak Asasi Manusia, HAM adalah seperangkat hak yang melekat pada hakikat dan keberadaan manusia sebagai makhluk Tuhan Yang Maha Esa dan merupakan anugrah-Nya yang wajib dihormati, dijunjung tinggi, dan dilindungi oleh negara, hukum, pemerintahan, dan setiap orang demi kehormatan serta perlindungan harkat dan martabat manusia.

Undang-Undang Nomor 39 Tahun 1999 tentang Hak Asasi Manusia, terbagi atas sepuluh katagori. Hak untuk hidup dalam undang-undang ini diatur dalam Bab II pasal 4, yang menyatakan bahwa hak hidup adalah hak yang dimiliki oleh setiap orang dan tidak boleh dirampas sebagian atau seluruhnya dalam keadaan apapun dan oleh siapapun, dalam Bab III pasal 9 ayat (1), yang menyatakan bahwa tiap orang berhak untuk hidup dan mempertahankan kehidupannya serta dalam pasal 33 ayat (2), yang menyatakan bahwa tiap orang bebas dari perasaan takut akan penghilangan paksa dan penghilangan nyawa. Jika dikaitkan dengan eutanasia, tindakan eutanasia ini sangat bertentangan dengan pasal 4 , pasal 9 ayat (1), dan pasal 33 ayat (2) UU Nomor 39 Tahun 1999 tentang Hak Asasi Manusia. Terdapat beberapa pasal dalam UUD Negara Republik Indonesia 1945 yang mengatur tentang HAM dan berkaitan dengan eutanasia, yaitu pasal 28A, pasal 28G ayat 2, dan pasal $28 \mathrm{I}$.

\section{Eutanasia Dipandang dari Perspekif Hukum Positif di Indonesia}

Kejahatan pada tubuh dan nyawa diatur dalam KUHP, terdiri dari kejahatan terhadap tubuh atau penganiayaan (pasal 351-361 KUHP) dan kejahatan terhadap nyawa atau pembunuhan (pasal 338-350). Kitab Undang-Undang Hukum Pidana tidak ada menyebut tentang eutanasia. Dalam hal eutanasia, pelakunya dapat diancam dengan pasal dalam KUHP, yaitu pasal 338, 340, 344, dan 345 (Chazawi, 2017).

Dari pandangan hukum positif Indonesia, tindakan eutanasia adalah suatu pembunuhan. Menurut Moeljatno, dalam Pradjonggo (2016), secara yuridis formal dalam hukum pidana positif di Indonesia, hanya dikenal dua macam eutanasia, yaitu eutanasia aktif (eutanasia yang dilakukan atas permintaan pasien) dan eutanasia pasif (eutanasia yang dilakukan dengan sengaja melakukan pembiaran terhadap pasien).

Untuk eutanasia aktif, pelaku dapat dikenakan pasal 344 KUHP. Perbedaan nyata antara pembunuhan pasal 344 KUHP dengan pembunuhan pasal 338 KUHP, terletak bahwa pada pembunuhan pasal 344 KUHP terdapat unsur-unsur atas permintaan korban sendiri, yang jelas dinyatakan dengan sungguh-sungguh, dan tidak dicantumkanya unsur kesengajaan sebagaimana yang dirumuskan dalam pasal 338 KUHP. Unsur atas permintaan korban membuktikan bahwa inisiatif untuk melakukan pembunuhan terletak pada korban itu sendiri (Sutarno, 2014).

Pasal 304, 306, dan 531 KUHP menyatakan bahwa meninggalkan orang yang perlu ditolong juga dimasukan sebagai tindak pidana. Hal ini menegaskan dilarangnya eutanasia pasif di Indonesia. Peristiwa pasien yang meminta pulang paksa kemudian diijinkan oleh dokternya dapat digolongkan sebagai eutanasia pasif. Walaupun dokter beralasan, bahwa pasien dipulangkan karena menghormati hak pasien, padahal dokter mengetahui akibat tindakan pulang paksa tersebut terhadap pasien. Dokter dapat dianggap melakukan pembiaran pasien di rumah sehingga pasien meninggal dunia.

Pasal lain dalam KUHP yang dapat dikaitkan dengan eutanasia adalah pasal 340 dan pasal 359. Dokter dan keluarga yang memberikan ijin untuk dilakukan tindakan eutanasia dapat dikenakan pasal 345 KUHP yang menyatakan barang siapa dengan sengaja menyarankan orang lain untuk bunuh diri atau memberikan sarana kepadanya untuk itu, diancam dengan pidana penjara selama-lamanya empat tahun penjara.

Jika tindakan eutanasia dilakukan oleh beberapa orang (dokter, perawat atau tenaga medis lainnya, keluarga pasien), maka yang melakukan, yang menyuruh melakukan atau turut melakukan akan dihukum sebagai orang yang melakukan tindakan pidana atau juga sebagai orang yang salah memakai kekuasaan atau pengaruh. Dalam hal membantu tindakan eutanasia, maka pelaku-pelakunya (dokter, perawat atau tenaga kesehatan yang lain, keluarga pasien) dapat dikenakan pasal 56 dan pasal 57 KUHP.

Pada kasus eutanasia di Indonesia, tidak cukup hanya mendasarkan hukumnya pada KUHP tetapi banyak pertimbangan hukum yang dapat digunakan termasuk doktrin dalam ilmu pengetahuan kedokteran. Saat dimana payung hukum dalam tindakan eutanasia tidak ada, maka akan dengan mudah dokter digugat. Namun tentu ada pertimbangan lain dengan merujuk pada ilmu pengetahuan kedokteran 
sebagai sumber hukum dan ilmu hukum yang ditulis oleh para ahli hukum yang menyebutkan pendapat yang berbeda.

Secara yuridis, tindakan eutanasia merupakan tindakan pidana. Namun tidak semua orang yang melakukan tindakan pidana dapat dihukum. Kitab Undang-Undang Hukum Pidana Bab III menyebutkan tentang hal-hal Menghapuskan, Mengurangi atau Memberatkan Pidana, terutama pada pasal 48. Pasal 48 KUHP ini lebih melihat kepada daya paksa yang bersifat fisik. Dalam perkembangan ilmu pengetahuan dan teknologi kedokteran, pengaruh daya paksa ini dapat diartikan secara fisik dan psikis. Dalam hal merawat pasien yang tidak mungkin dapat disembuhkan kembali, dokter yang merawat akan merasa sangat kasihan kepada pasiennya bahkan dapat menderita bathinnya. Ini merupakan salah satu contoh daya paksa psikis.

Jadi dokter yang melakukan tindakan eutanasia dapat dianggap telah melakukan tindak pidana. Namun, dokter tidak dibebani pertanggungjawaban pidana atau mendapatkan keringanan hukuman atau bahkan pembebasan hukum jika merunut pasal 48 KUHP secara extension.

Perilaku dokter diatur di dalam sebuah pedoman, yaitu Kode Etik Kedokteran Indonesia (KODEKI). Pedoman ini tidak hanya mengatur dokter dalam menjalankan tugasnya saja tetapi juga mengatur hubungan dokter dengan masyarakat sehari-harinya. Perilaku dokter diharapkan mencerminkan perilaku yang terpuji karena profesi dokter adalah profesi yang luhur. Dokter akan menjalankan profesinya dengan niat yang luhur dan jalan yang benar. Masyarakat tidak perlu cemas bahwa eutanasia akan dengan sangat mudah dilakukan oleh seorang dokter walaupun dokter adalah manusia yang tidak mungkin lepas dari kesalahan diperlukan payung hukum untuk mengontrol tindakan eutanasia ke depannya.

\section{SIMPULAN DAN SARAN Simpulan}

Apabila Eutanasia dipandang dari perspektif Hak Asasi Manusia maka sangat bertentangan dengan beberapa pasal dalam UUD Negara Republik Indonesia 1945 yang mengatur tentang hak asasi manusia, antara lain: pasal 28A, pasal 28G ayat (2), dan pasal 28I ayat (1). Selain bertentangan dengan pasalpasal tersebut, tindakan eutanasia juga bertentangan dengan pasal 4, pasal 9 ayat (1), dan pasal 33 ayat (2) UU Nomor 39 Tahun 1999 tentang Hak Asasi Manusia. Kemudian, dalam konteks hukum positif di Indonesia, sampai saat ini belum ada aturan khusus yang mengatur pelaksanaan eutanasia di Indonesia. Pelaku tindakan eutanasia di Indonesia masih diancam dengan pasal 338 KUHP, 340 KUHP, 344 KUHP dan 345 KUHP.

Beberapa pasal lain yang dapat dikaitkan dengan pelaku eutanasia, antara lain: pasal 304 KUHP, pasal 306 KUHP, pasal 340 KUHP, pasal 345 KUHP, pasal 359 KUHP, dan pasal 531 KUHP. Pihakpihak lain (dokter, perawat, tenaga kesehatan, keluarga pasien) yang membantu tindakan eutanasia dapat dikenakan pasal tambahan, yaitu pasal 55-62 KUHP tentang penyertaan.

\section{Saran}

Dalam hal permintaan eutanasia yang berasal dari pasien atau keluarga pasien, sebaiknya dokter menolak permintaan tersebut sebab seorang dokter harus berpedoman pada norma tertulis dan tidak tertulis dalam bekerja atau keinginan yang kuat dari pasien atau keluarga pasien untuk melakukan tindakan eutanasia, sebaiknya disampaikan ke Komite Medik dan putusan pelaksanaan eutanasia sebaiknya menunggu penetapan putusan pengadilan. Namun, ketiadaan norma hukum yang mengatur eutanasia, diharapkan payung hukum untuk mengontrol tindakan eutanasia ke depannya supaya profesi dokter mendapat perlindungan hukum.

\section{DAFTAR PUSTAKA}

Baeke, G., Wils, J. P., \& Broeckaert, B. (2011). “We are (not) the Master of Our Body”: Elderly Jewish Women's Attitudes towards Euthanasia and Assisted Suicide. Ethnicity and Health, 16(3), 259-278.

Chazawi, A. (2017). Kejahatan terhadap Tubuh dan Nyawa (7th ed.). Depok: PT Raja Grafindo Persada.

Marshall, J. C., Bosco, L., Adhikari, N. K., Connolly, B., Diaz, J. V, Dorman, T., Zimmerman, J. et. al. (2017). What is an Intensive Care Unit? A Report of the Task Force of the World Federation of Societies of Intensive and Critical Care Medicine. Journal of Critical Care, 37, 270-276.

Pradjonggo, T. S. (2016). Suntik Mati (Euthanasia) Ditinjau dari Aspek Hukum Pidana dan Hak Asasi Manusia di Indonesia. Jurnal Ilmiah Pendidikan Pancasila Dan Kewarganegaraan, 1(1), 57-59. 
Qamar, N. (2016). Hak Asasi Manusia Dalam Negara Hukum Demokrasi (3rd ed.). Jakarta: Sinar Grafika.

Sofyan, A. (2017). Euthanasia: Concept and Rule of Law in Indonesia. Journal of Law, Policy and Globalization, $58(0), 27-32$.

Sutarno. (2014). Hukum Kesehatan Eutanasia, Keadilan, dan Hukum Positif di Indonesia. Malang: Setara Press. Sutarno. (2020). Euthanasia from the Perspective of Indonesian Norms. Systematic Reviews in Pharmacy, 11(1), 192-202.

Yustina, E. W. (2018). Withdrawing Life Supports Therapy in Human Rights Perspective. Journal of Advances in Health and Medical Sciences, 4(2), 32-42.

Kitab Undang-Undang Hukum Pidana.

Undang-Undang Dasar Negara Republik Indonesia 1945.

Undang-Undang Republik Indonesia Nomor 39 Tahun 1999 tentang Hak Asasi Manusia. 